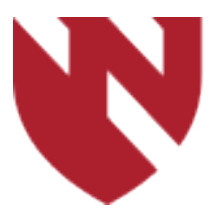

September 2020

\title{
High-Persensitivity Pneumonitis
}

\author{
Daniel VanKalsbeek \\ University of Nebraska Medical Center \\ Daniel Hershberger \\ University of Nebraska Medical Center
}

Tell us how you used this information in this short survey.

Follow this and additional works at: https://digitalcommons.unmc.edu/gmerj

Part of the Higher Education Commons, and the Medicine and Health Sciences Commons

\section{Recommended Citation}

VanKalsbeek, D., , Hershberger, D. High-Persensitivity Pneumonitis. Graduate Medical Education Research Journal. 2020 Sep 29; 2(1).

https://digitalcommons.unmc.edu/gmerj/vol2/iss1/84

This Conference Proceeding is brought to you for free and open access by DigitalCommons@UNMC. It has been accepted for inclusion in Graduate Medical Education Research Journal by an authorized editor of DigitalCommons@UNMC.For more information, please contact digitalcommons@unmc.edu. 


\section{High-Persensitivity Pneumonitis}

\section{Creative Commons License}

\section{(c) (i) (2)}

This work is licensed under a Creative Commons Attribution-Noncommercial-No Derivative Works 4.0 License. 


\section{References}

1 Goldstein, N. P., Frey, S. M., Fagnano, M., Okelo, S. O., \& Halterman, J. S. (2018). Identifying Which Urban Children With Asthma Benefit Most From Clinician Prompting: Subgroup Analyses From the Prompting Asthma Intervention in RochesterUniting Parents and Providers (PAIR-UP) Trial. Academic Pediatrics, 18(3), 305-309. doi:10.1016/j. acap.2017.08.015

2 Khasha R, Sepheri MM, Mahdaviani SA. (2019). An ensemble learning method for asthma control level detection with leveraging medical knowledge-based classifier and supervised learning. Journal of Medical Systems, 43(6):158. doi: 10.1007/s10916-019-1259-8

3 Rojanasarot S and Carlson AM. (2017). The Medical Home Model and Pediatric Asthma Symptom Severity: Evidence from a National Health Survey. Population Health Management, 21(2):130-138. doi: 10.1089/pop.2017.0066
4 Ruffner MA, Henrickson SE, Chilutti M, Grundmeier R, Spergel JM, Brown-Whitehorn TF. (2018). Improving office scheduling increases patient follow up and reduces asthma readmission after pediatric asthma hospitalization. American College of Asthma, Allergy, and Immunology, 121(5):561-567. doi: 10.1016/j.anai.2018.08.015

5 Sommer SJ, Queenin L.M., Nethersole S, Greenberg J. (2011). Children's hospital Boston community Asthma initiative: partnerships and outcomes advance policy change. - Prog Community Health Partnersh, 5(3):327-35. doi:10.1353/cpr.2011.0044

\section{High-Persensitivity Pneumonitis Daniel Van Kalsbeek ${ }^{1}$, Daniel Hershberger ${ }^{2}$}

${ }^{1}$ Department of Internal Medicine, University of Nebraska Medical Center,

${ }^{2}$ Department of Internal Medicine, Division of Pulmonary and Critical Care Medicine, University of Nebraska Medical Center,

Mentor: Daniel Hershberger

Program: Internal Medicine

Type: Case Report

Introduction: Hypersensitivity pneumonitis (HP) is an immune-mediated lung disease characterized by parenchymal inflammation following inhalation of an inciting antigen.

Case Report: A middle-aged woman was admitted with sub-acute respiratory failure. Physical exam revealed a euvolemic woman with coarse breath sounds who was requiring supplemental oxygen. She had two prior hospitalizations for similar but less severe symptoms. Her previous episodes appeared to respond to antibiotics though required her to go home on oxygen. Chest CT revealed diffuse bilateral consolidations, and a leukocytosis was present. Broad spectrum antibiotics were initiated. There was no clinical improvement at 24 hours so TMP/ SMX plus corticosteroids were added to her treatment plan. She promptly improved. A hypersensitivity panel was positive for antibodies against Aspergillus species. Exposure history uncovered marijuana use that coincided with her current and prior respiratory symptoms. Hypersensitivity pneumonitis was diagnosed. She was discharged on a steroid taper and strict marijuana avoidance. At six-week follow up her symptoms had completely resolved. Discussion: Environmental fungi are wellestablished triggers for HP. They are able to pass through lit marijuana cigarettes and pipes, particularly the spores of A. fumigatus. Knowing this we felt confident making the diagnosis of HP in our patient because of her positive hypersensitivity panel plus her history of marijuana use coinciding with her symptoms. Her symptoms resolved with corticosteroids and abstinence from marijuana.

Conclusion: Marijuana harbors organic antigens and should be explored as a trigger for hypersensitivity pneumonitis.

https://doi.org/10.32873/unmc.dc.gmerj.2.1.083

\section{Improving the Efficiency of Same-Day III Calls}

Tracy Farrell', Teri L. Schuldt ${ }^{1}$, Mary Wells ${ }^{1}$, R. Gregory Bociek ${ }^{1}$

${ }^{1}$ University of Nebraska Medical Center, Department of Internal Medicine, Division of Oncology and Hematology

\section{Mentor: R. Gregory Bociek}

Program: Internal Medicine, Division of Oncology and Hematology

Type: Original Research

Background: We sought to use quality improvement (QI) methodology to approach problems leading to burnout and workplace stress in our oncology care team.

Methods: Through a broad survey, we identified coordination of same-day, outpatient visits for acutely ill oncology patients as a source of excessive stress for team members across various disciplines including case managers, infusion clinic nurses, advanced practice providers, and physicians. We used the Plan-Do-Study-Act (PDSA) framework to identify a feasible, appropriate intervention to reduce case manager time required to coordinate visits with the specific aim of reducing their time by $25 \%$. We also tracked phone calls required to arrange a visit and perceived frustration with the process. Our intervention involved transitioning from paging individual practitioners to using HIPPA-compliant group text to collaboratively coordinate care.

Results: After one PDSA cycle, we found case manager time required to arrange a visit had de-creased by $21 \%$, number of calls required by $59 \%$ and frustration with the process by $41 \%$.
Conclusion: While we did not meet our specific aim, we feel use of a QI approach led to an easily implemented, effective modification to streamline a previously inefficient, disruptive workflow. The use of QI methodology ensured we understood the baseline process and involved all stakeholders before implementing a change and also ensured we followed data to understand our intervention's impact on team members. Viewing sources of burnout and workplace frustration through the lens of QI may lead to more consistently high-yield interventions than traditional wellness-based, administrative approaches.

https://doi.org/10.32873/unmc.dc.gmerj.2.1.084 